\title{
Research on Chinese Influence on Western Fashion Based on Fashion Magazine from 1970 to 1979
}

\author{
Yuru $\mathrm{Ma}^{1} \&$ Xiangyang Bian ${ }^{1}$ \\ ${ }^{1}$ Fashion \& Art Design Institute, Donghua University, Shanghai, China \\ Correspondence: Xiangyang Bian, Fashion \& Art Design Institute, Donghua University, 1882 West Yan'an Road, \\ Changning District, Shanghai, China. Tel: 137-0171-5417. E-mail: bianxiangyang@163.com \\ Received: November 28, 2019 \\ Accepted: December 28, 2019 \\ Online Published: January 31, 2020 \\ doi:10.5539/ass.v16n2p11 \\ URL: https://doi.org/10.5539/ass.v16n2p11
}

\begin{abstract}
The decade of 1970s was a peak of Chinese influence on Western fashion. This article was intended to reveal the categories and design characteristics of Chinese-influenced clothing with classified statistical method based on collecting a total of 295 sets of designs presented during 1970-1979 from four fashion magazines. The underlying reasons for the popularity of Chinese-influenced clothing on western fashion were also analyzed and summarized. The research results showed that the Chinese-influenced clothing included three categories: outdoor daily clothes, indoor home wears and evening dresses, presenting neutral, romantic and luxury respectively. The popularity of Chinese-influenced clothing was mainly a result of some national and international factors, including anti-fashion aesthetics in the western society, the normalization of Sino-American relation and the development of Hong Kong trade.
\end{abstract}

Keywords: China, dress, history, design, western

Chinoiserie was originated from French when the maritime trade developed between China and France in 16th century. Large quantities of Chinese arts and crafts were imported into Europe, thus inducing a Chinese-style boom there in 18th century. Reflected in decorative design, Chinoiserie is a kind of elegant, gorgeous and exotic decorative style, that mixes with the traditional Western aesthetic temperament and interest, rather than the pure Chinese style. Chinese culture has been influencing the Western textile and clothing for many centuries, especially for the period of reform and opening up in China since 1970s (Zeng, 2011, pp. 110-111). The "Chinoiserie" in the 18th century was mainly reflected in the design of textile patterns, clothing styles and colors. After the 19th century, western clothing began to be more influenced by China in terms of fabrics, patterns, styles and colors (Bian, 2006, p. 190). During this period, as an exotic style, Chinese clothing were only sought after by western designers, but did not form a lasting trend. However, in 1970s, Chinese-influenced clothing became popular in Europe and America. Young French fashion editors began sporting anti-fashion work uniforms imported from the People's Republic of China (Steele, 1999, p. 78). Fashion designers also began creating their own high-style versions of Chinese apparel. The special appeal of Chinese clothing, the Han suit, the cheongsam and the Mao suit (Chinese uniform) has inspired many western fashion designers (Zeng, 2011, p. 8). Chinese aesthetics was typically applied on the garment fabrics, dress patterns, clothing styles and details, with fusion of the age characteristics. A large number of excellent modern fashion full of Chinese interest and charm came into being, creating a new style of Chinese themed fashion design and laying the foundation of modern and contemporary Chinese style fashion design.

Due to Chinese growing influence on western fashion, related research started to spring up from various perspectives. Kim and DeLong (1992) analyzed Japanese and Chinese influence in both visual and written information as depicted in Harper's Bazaar from 1890-1927. Yu et al. (2001) discussed contemporary fashion influenced by Asian ethnic dress, focusing on China, Indonesia, Japan, Korea and Vietnam. Delong, Wu and Bao (2005) compared the aesthetic cognition of Chinese students and American students on contemporary Chinese-influenced dresses by using questionnaire survey method. Xu (2003) studied the artistry and aesthetic nature of Chinese-influenced clothing in the West. Some of the above-mentioned studies involved typical design cases during the 1970s, but most were still far from being all-inclusive and in-depth.

Fashion media, the carrier and the driving force of modern trends, contain TV programs, magazines, newspapers and enterprise journals. In 1892, a magazine named Vogue was first published in the United States. Ever since 
then, fashion magazines became an important medium for displaying, promoting and making fashion waves. These magazines kept all changes about females, trends, concepts of politics and culture throughout the 20th century.

The purpose of this study was to explore the forms and features of Chinese-influenced clothing in 1970s and indicates the social roots of its prevalence in western countries by classifying and analyzing the images of Chinese-influenced clothing shown in noted fashion magazines, including Vogue (American Edition), Harpers and Queen (American Edition \& British Edition) and Women's Wear Daily (WWD). The study was conducted to provide Chinese and western designers with past records and aesthetic contemplation on Chinese-influenced clothing worldwide. It would be of certain reference value in greeting a long-term future for the Chinese-influenced clothing design.

\section{Introduction}

In the past five thousand years, the Chinese people have created many beautiful clothing styles. During that time, Chinese clothing has undergone changes in most dynasties. Each period of history has its own unique, but each period of clothing has a subtle relationship, mutual learning, continuous development. In the history of Chinese clothing, although there are various kinds of clothing, only three periods of clothing have a significant impact on western fashion. They are the Qing dynasty (1644-1911), the Republic of China (1912-49), and the People's Republic of China (1949-present) (Bolton, 2015, pp. 18-19). In the Qing dynasty, Manchu women wore the traditional cheongsam, also known as Manchu Robe, and Han women wore Han suits. In the republic of China, most Chinese women wore modern Cheongsam, which was a kind of fit dress with side seam. During the People's Republic of China, most people wore Mao suits.

\subsection{Han Suit}

Han suit, which literally means "clothes of Han people," refers to the traditional clothing of the Han Chinese, which accounts for more than 93 percent of China's population. The dresses of the Han Chinese have many styles in different dynasties. Because of the policy of the government in Qing dynasty, Han men in the Qing dynasty had to wear manchu robes, and Han women wore Han suits. At that time, Han suit mainly consisted of several clothes: 1) Top: Shan: a kind of shirt or jacket with cross-collar, side or central open. Ao: The same type with Shan but added cotton quilted. 2) bottom: skirt or trousers. Han suit is characterized by wide and loose sleeves and a very loose fit (Zhou \& Gao, 1984) (Figure 1). Han suit is often with luxuriant inlay roll, embroidery serves as adornment gimmick, and fabrics to silk, crepe, satin-based. It also has frog buttons and embroidered edges as decoration. The Han suit in the republic of China was more simplified, more fitting and simpler in decoration. The embroidery edges were gradually simplified into pipes (Figure 2).

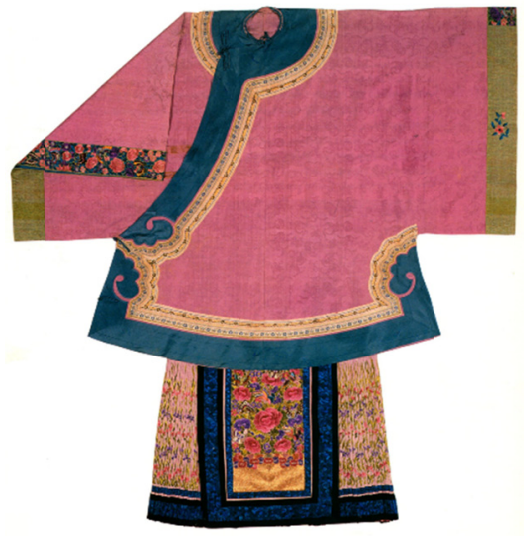

Figure 1. Han suit in Qing dynasty (Szeto, 1997)

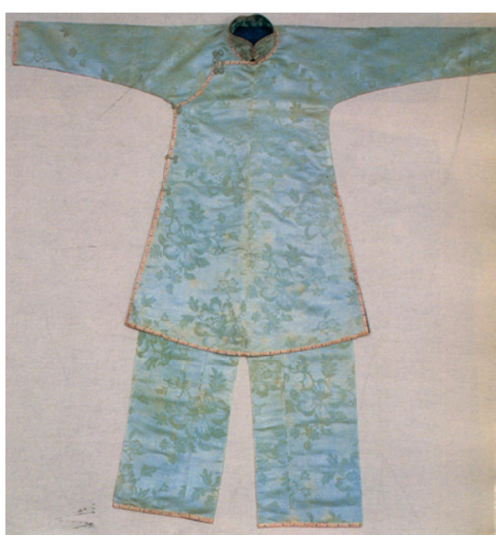

Figure 2. Han suit in the Republic of China (Szeto, 1997)

\subsection{Cheongsam}

Cheongsam is a kind of one-piece robe that combines manchu, Chinese and western elements. It was originally from Manchu cheongsam in the Qing dynasty. Manchu cheongsam featured a round neck and a panel crossing from left to right, fastening at the side with five buttons and loops (Zeng, 2010, p.13). A slit at the sides of the body of allows for daily activities. The collar, cuff, side and hem were decorative embroidered. Trousers are usually worn under a cheongsam (Figure 3). By the early 20th century, under the influence of western clothing, Manchu cheongsam had undergone significant changes, also known as the modern cheongsam. It changed from 
a flat structure into a three-dimensional structure, which was more fit and highlights feminine features; from silk materials and style to various fabrics, shapes and details. The stand collar or mandarin collar was one of the essential features of modern cheongsam, and became a symbol of Chinese costume (Figure 4).

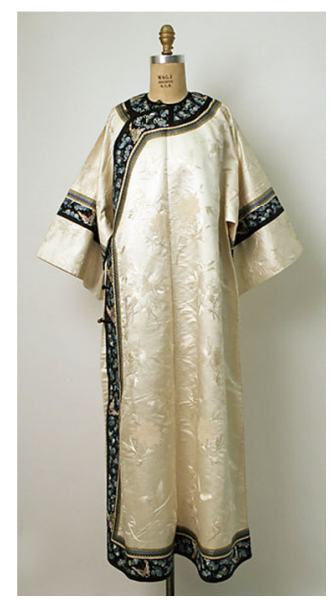

Figure 3. Manchu cheongsam in Qing dynasty (Metropolitan Museum of Art)

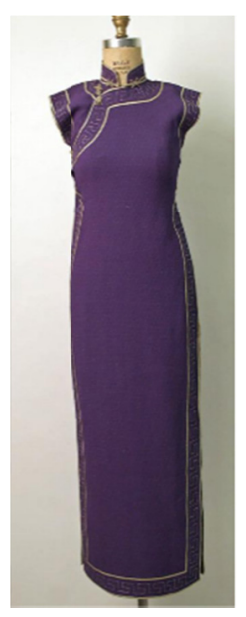

Figure 4. Modern cheongsam in the Republic of China (Metropolitan Museum of Art)

\subsection{Mao Suit}

"Mao suit" is an umbrella term for the Zhongshan tunics, Chinese uniforms and other similar styles worn by Chinese men and women during the Mao era (1950-70). Mao suit is a kind of modern male attire in China, and originated from Zhongshan suit, which was worn by young Chinese politicians in 1920s to promote revolutionary activities (2019). Mao zedong's love of this style led to some minor improvements, which became popular in China after 1949. The Mao suit consisted of a tunic with a high collar, four pockets, five buttons, trousers and cotton Chinese-style shoes, forming the basic elements of communist clothing (Steele, 1999, p. 6) (Figure 5). Sometimes, Western fashion writers describe it as a "Chinese tunic suit"or "Chinese uniform".

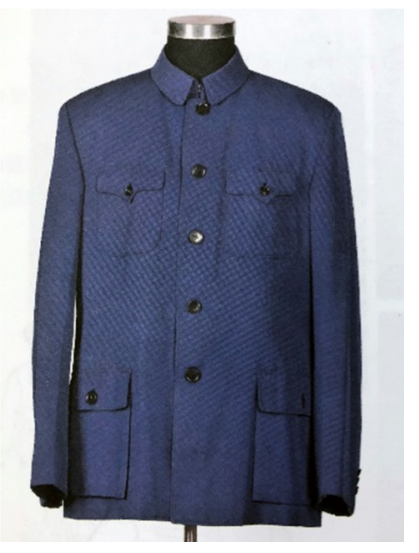

Figure 5. Mao jacket (Bian, 2014)

\section{Methodology}

\subsection{Clothing Images Collection}

I selected fashion magazines with continuous coverage from 1970 to 1979 as sources of information to analyze Chinese influence. Vogue (American Edition), Harpers and Queen (American Edition \& British Edition) and Women's Wear Daily were chosen due to their authoritative as fashion magazines, their coverages of the entire period, and its availability. With the exclusion of men and children's wear, I collected a total of 295 Chinese-influenced women's clothing images by consulting every issue of magazines above in the 1970s. The clothing were collected in accordance with the following standards: 1. Written References (i.e. phrases in relation to Chinese garments for reference): occurrences of "Chinese" and "Chinoiserie" in the caption and introduction of a garment; descriptions of clothes types, like "Cheongsam", "Mao suit", "Mandarin jacket", "Chinese y-tunic", etc.; names of garment parts, like "Frog-button", "Mandarin-collar", "Chinese-sleeved", etc. 
2.Visual Reference (i.e. the Chineseness directly reflected in a garment for reference).

\subsection{Clothing Images Classification}

According to different scenes of dressing, the collected clothing images were sorted into daily wear and evening dress. Daily wear means the clothes worn in one's daily life, including outdoor clothes and loungewear. Outdoor clothes was defined by the occurrences of "Work suit", "For day", "Sportswear" and the like in captions or introductions in the magazines, Loungewear by "Pajamas", "sleeping gown", "At home", etc.

Evening dress is a kind of formal attire. In general, formal attire embraces all types of clothes worn on formal occasions, in which a kind of grandeur, solemnity, elegance and beauty can be felt. In a narrow sense, formal attire refers to women's evening dress, a must for western women to attend social activities at places of rituality. Evening dress was classified according to the occurrence of "Restaurant dressing" or "For dinner", "Evening dress" in clothing captions and introductions.

From the perspective of design, types, colors and fabrics are the major components of clothing design. Besides, it was commonly seen that western designers expressed Chinese elements in the form of patterns and decoration crafts. Proceeding from the above-mentioned components supplemented by patterns and decoration crafts, this essay attempted to offer an interpretation about Chinese-influenced women's wear.

In terms of clothing types, there were three major types of costumes in China that had the strongest impact on the West. They were Cheongsam, Han suit and Mao suit. In terms of colors, since images of 70 s fashion magazines were mostly black and white, the selection of colors relied mainly on written reference. As to some images in more than one color, the bottom color accounting for the largest proportion was selected as the color of the material. In terms of fabrics, the selection was made with the written reference of the material, such as cotton, silk, natural fiber fabrics and chemical fiber fabrics and mixed fabric of fibers, etc. In terms of patterns, clothing images were classified into two categories: with patterns and without patterns. Patterned clothing included flower plant patterns, text patterns, and geometric patterns. In terms of decoration crafts, it was divided into graphic decoration, three-dimensional decoration and a combination of graphic and three-dimensional decoration. Graphic decoration mainly contained embroidery and printing on the fabric. The three-dimensional decoration included frogs, piping trim, quilting, and the like.

Therefore, the clothing images were classified in three categories: The first one was the dressing scene category, comprising outdoor clothes, loungewear and evening dress; the second one was the design element category, which consisted of types, colors, fabrics, patterns and decoration crafts. The third one was the specific content corresponding to the design element category. Images classification rules ware shown in Figure 6.

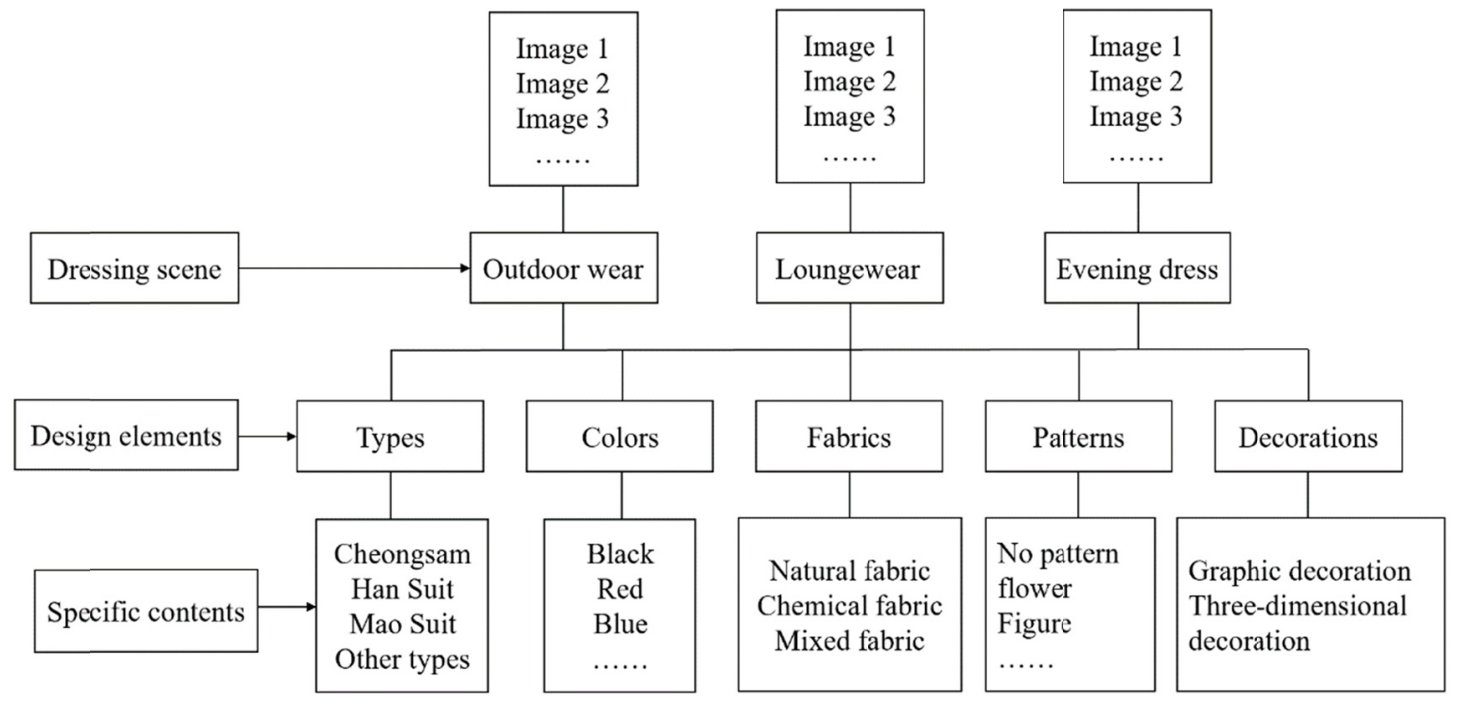

Figure 6. Chinese-influenced clothing images processing rules

\section{Data Analysis}

As can be seen in the statistics about 295 images of Chinese women's clothing in fashion magazines of the 1970s, there were 142 outdoor outfits that occupy $48 \%$ of the total number, 50 lounge wears that take over $17 \%$, and 103 evening dresses accounting for $35 \%$. Outdoor clothes were the main category of Chinese women's wear in western countries during the 1970s (Table 1). 
Table 1. Classification statistics of Chinese-influenced clothing

\begin{tabular}{|c|c|c|c|c|c|c|}
\hline elements & $\begin{array}{l}\text { Images of outdoor } \\
\text { wear }\end{array}$ & QT & Images of loungewear & QT & Images of evening dress & QT \\
\hline \multirow{4}{*}{$\begin{array}{l}\text { Types (from most } \\
\text { to least) }\end{array}$} & Han suits & 56 & Cheongsams & 20 & Cheongsams & 56 \\
\hline & Mao suits & 50 & Han suits & 14 & Han suits & 25 \\
\hline & Cheongsams & 13 & Other types & 11 & Other types & 17 \\
\hline & Other types & 23 & Mao suits & 5 & Mao suits & 5 \\
\hline \multirow{4}{*}{$\begin{array}{l}\text { Colors (Top } 4 \\
\text { colors from most } \\
\text { to least) }\end{array}$} & Black & 16 & Red & 9 & Black & 25 \\
\hline & Dark blue & 10 & Peach and pink & 7 & Red & 13 \\
\hline & Khaki & 9 & White & 5 & Blue & 8 \\
\hline & Grey/White & 6 & Light blue & 4 & Violet/Orange & 6 \\
\hline \multirow{4}{*}{$\begin{array}{c}\text { Fabrics (Top } 4 \\
\text { shell fabric from } \\
\text { most to least) }\end{array}$} & Cotton & 56 & Silk & 35 & Silk & 58 \\
\hline & Silk & 27 & Cotton & 4 & Chemical fiber & 15 \\
\hline & Woolen fabric & 21 & Chemical fiber & 4 & Mixed fabric & 10 \\
\hline & Mixed fabric & 14 & Mixed fabric & 2 & Cotton & 5 \\
\hline \multirow{4}{*}{$\begin{array}{l}\text { Patterns (from } \\
\text { most to least) }\end{array}$} & No pattern & 88 & No pattern & 21 & $\begin{array}{c}\text { Patterns of flowers and } \\
\text { plants }\end{array}$ & 57 \\
\hline & $\begin{array}{l}\text { Patterns of flowers and } \\
\text { plants }\end{array}$ & 25 & $\begin{array}{c}\text { Patterns of flowers and } \\
\text { plants }\end{array}$ & 20 & No patterns & 29 \\
\hline & Geometric patterns & 21 & Geometric patterns & 5 & Geometric patterns & 6 \\
\hline & Other patterns & 8 & Patterns of animals & 4 & Other patterns & 5 \\
\hline \multirow{4}{*}{$\begin{array}{l}\text { Decoration Crafts } \\
\text { (from most to } \\
\text { least) }\end{array}$} & $\begin{array}{l}\text { Three-dimensional } \\
\text { decoration }\end{array}$ & 77 & $\begin{array}{c}\text { A combination of } \\
\text { decorations }\end{array}$ & 22 & $\begin{array}{l}\text { A combination of } \\
\text { decorations }\end{array}$ & 49 \\
\hline & No decoration & 44 & $\begin{array}{c}\text { Three-dimensional } \\
\text { decoration }\end{array}$ & 17 & $\begin{array}{c}\text { Three-dimensional } \\
\text { decoration }\end{array}$ & 35 \\
\hline & Graphic decoration & 19 & Graphic decoration & 7 & Graphic decoration & 15 \\
\hline & $\begin{array}{l}\text { A combination of } \\
\text { decorations }\end{array}$ & 2 & No decoration & 4 & No decoration & 4 \\
\hline
\end{tabular}

Note. QT= Quantity.

\section{Features of Chinese-influenced Women's Wear in the 1970s}

It can be learned from the statistics narrated above that Chinese-influenced clothing in the 1970s were divided into three categories: outdoor clothes, loungewear and evening dresses, each having its own styles and features. Most of them were adopted the shape and style of Chinese clothing, but made changes and innovations in colors, fabrics and details.

\subsection{Chinese-influenced Outdoor Wear}

As can be seen in the statistics, most Chinese-influenced outdoor clothes were mainly designed from Mao suits and Han suits. Table 2 shows the different types of Chinese-influenced outdoor clothes. Shown in Figure A, an outdoor suit, was included in a report in Vogue on April 4 1975. Inspired by Mao suit, the upper part of the suit was a stand - collar, open - cut suit with four big pockets, while the lower part was black slacks. Figure B was a perfect Chinese tunic made by Marc Bohan for Christian Dior. Ivory crêpe with thin black passementerie edging, a tasseled passementerie belt wrapped and the frog button indicated the Chinese influence. Figure $\mathrm{C}$ shows a model wearing a central opening Han suit-influenced garment, which was made by cotton. The mandarin collar, black roll edge and the frog buttons show Chinese features. The editor also indicated that BOLLS defines Chinoiserie with a charming quilted tobacco Chinese jacket in 100\% cotton, piped in black...reversing to tan-and-white stripes for another great sportswear look (Vogue, 1976 August 1, p. 37).

Although the outdoor clothes were influenced by different types of Chinese clothing, they had the same features. The clothes were made of natural fabrics like cotton, wool and silk. Most of them were put stress on functional decorations instead of fancy patterns; they were often in dark colors or achromatic colors, such as black, dark 
blue, khaki grey and white. These garments had been improved by western designers into fashionable casual jackets, casual coats, overalls and sportswear for being loose and crisp, and became the most popular Chinese-influenced clothes featuring simplicity, leisure, functionality and neutrality in the 1970s.

Table 2. Different types of Chinese-influenced outdoor wears

\begin{tabular}{llll}
\hline Name & Mao suit influenced garment & Han suit influenced garment & Han suit influenced garment \\
Figures & Vogue 1973, October 4, p.154 Vogue 1975, August 1, p138 & Vogue 1976, August 1, p.37 \\
\hline
\end{tabular}

\subsection{Chinese-influenced Loungewear}

Chinese-influenced loungewear belonged to another major category of Chinese-influenced clothing. It was a popular and enduring view of Chinese robe as a cure for the impetuous tendencies of western society (Rado, 2015, p. 50). People's yearning for an eastern slow-paced lifestyle was reflected in the clothing. According to the statistical results, loungewear mostly included Han suits and cheongsam. The Han suit influenced loungewear in Figure D in Table 3 was the work of Chester Weinberg, published in American Vogue in November, 1971. The editor described it: Chinese-y evening pyjamas...tunic, two layers of lacquer-red flowered silk georgette, piped and frogged in bright lilac. . . matching rayon crèpe de Chine pants (Vogue, 1971 November 15, p. 68). In the same article, another figure showed a cheongsam-influenced loungewear (Figure E), which was made by white silk with frog buttons down the side.

In most Chinese-influenced loungewears in 1970s, silk-based natural fabrics were adopted with much attention paid to comfort; red, pink, peach, white and light blue being used as a stress on warm-toned and elegant colors; blankness and simple small floral patterns with very few circulations being frequently-used patterns with an impression of leisure, tenderness, and romance.

Table 3. Different types of Chinese-influenced loungewears

\begin{tabular}{lll}
\hline Name Han suit influenced garment & Cheongsam influenced garment \\
\hline Figures & & \\
& Vogue 1971, November $15, \mathrm{p} .68$ & Vogue 1971, November 15, p.71 \\
\hline
\end{tabular}




\subsection{Chinese-influenced Evening Dress}

As was shown in the statistical results, Chinese-influenced evening dresses of western countries stemmed from robes and cheongsams in the Qing Dynasty. Such dresses were often made of silk fabrics, adorned with a combination of both graphic decorations, such as exquisite embroidery and gorgeous printings, and structural decorations, such as piping and frogs, and matched with decorative materials like tassels, fur, sequins, metal wires, etc.. Patterns of dresses were mostly Chinese traditional graphic patterns apart from flowers and plants. This type of dresses was rich in colors like black, red, blue, purple, orange and others, building up a graceful, luxurious and splendid circumstance.

The dress in Figure F Table 4 was designed in the Yves Saint Laurent 1977/1978 Haute Couture collection, the image of which being included in the report titled"Paris Couture" from American Vogue. Inspired by the Manchu cheongsams, this dress was wrapped in a belt with tassels at a low-waist position. Its hem was high-pitched with royal blue brocade breeches revealed. The adoption of traditional dark blue brocade endowed the entire series with magnificent Chinese charm, on which were royal blue peony flowers embraced by golden branches and leaves. "Splendour" and "luxurious" were words picked by Yves Saint Laurent to describe it to express his longings for mysterious ancient China (Vogue, 1977 October, p. 263). His another work in 1979 Haute Couture collection (Figure G) was influenced by modern cheongsams, which was a high-necked, form-fitting dress with slit sides. The black jacquard silk fabric offered an exotic touch.

Table 4. Chinese-influenced evening dresses

Name Cheongsam influenced garment

\section{The Factors for the 70s Prevalence of Chinese-Influenced Clothing in Western Fashion}

The popularity of clothing, closely related to people's material life and spiritual life, is a reaction of people in a certain historical period. Factors affecting fashion trends include natural factors, social factors, and human factors. The phenomenon of China's influence on western fashion depends mainly on social factors, which could be split into internal and external factors.

\subsection{National Factors}

The 70s prevalence of Chinese-influenced clothing in West had its profound social origin. In the mid-late 1960s, there were fierce contradictions in western societies in the wake of worsening international political situations and economic situations. Some theorists threw doubts upon western traditional rationalism in the face of social unrest and crisis. As a result, anti-institutional thoughts against western traditions started to spread. In the meantime, new values gradually took shape. Such thoughts had been absorbed and exploited as a catalyst for hip culture by "Hippies", a youth group who was dissatisfied with the current state of society and free from bounds of traditional values, along with diversification and innovation of art and aesthetics. In fashion industry, it turned out to be an "anti-fashion" aesthetic trend that laid the foundation for Chinese style of arts and aesthetics different from traditional western values.

"Anti-fashion" refers to a general term for clothing styles that are obviously different from current trends (2019). 
Anti-fashion was first manifested as refusing to embrace fashion out of economic benefits or utilitarian purposes (Shi, 2018, p. 10). Consumers boycotted expensive and exquisite haute couture. Instead, they preferred worn-out, decadent items and bargains that stood for multiculturalism, street art and national elements. Ever since the Opium War, China has been taken by western societies as a melancholy country lagging behind. Moreover, with the pernicious effect of the stereotype, things went from bad to worse. It was reflected in George Barbier's depiction of decadent opium addicts in his illustration Chez la Marchande de Pavots and hideous features of Fu Manzhou in the film The face of Fu Manzhou of 1965, as is shown in Figure 7 and Figure 8. The foregoing negative impressions were misunderstandings about China from westerners, and yet catered to an opposing aesthetic trend against western modernism, which was overly refined, decent and positive. Traditional Chinese old gowns, short gowns worn by peasants, and other garments that look rough, worn-out or even patched were thereby redesigned as anti-fashion symbols. In the 1970s, such Chinese-influenced clothing, like the daily wear of coolies and workers, was frequently described with the word "Coolie" by western media as an indirect suggestion of shabbiness and low price. Although the word "Coolie" was marked with "Orientalism" to a certain extent, Chinese-influenced clothing still appeared now and then in the haute couture or ready-to-wear shows of Dior and Issey Miyake, conveying an Anti-fashion idea about durability and low cost proposed by the era of fuzzy fashion boundaries.

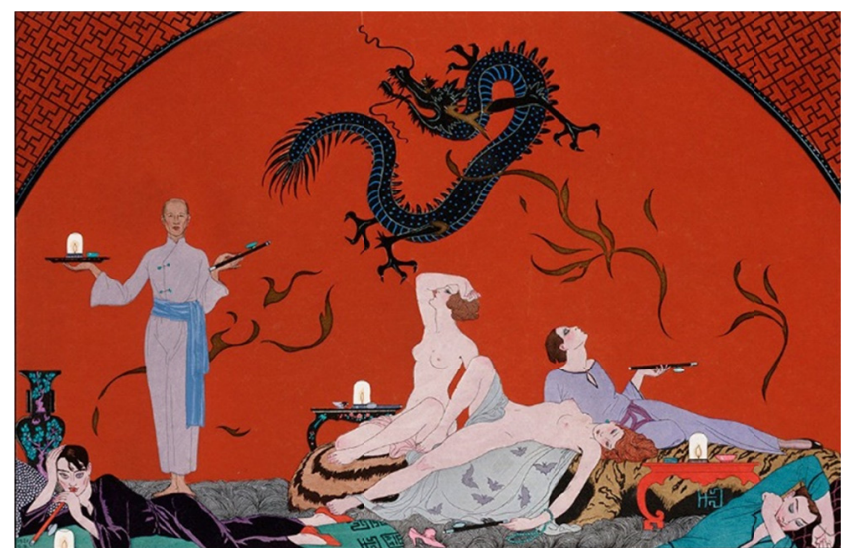

Figure 7. George Barbier(French, 1882-1932), <Chez la Marchande de Pavots $>$

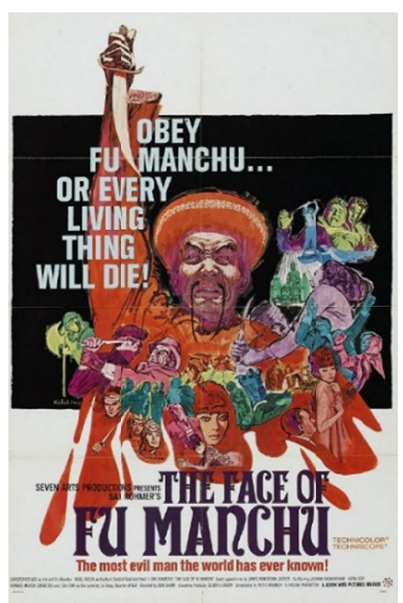

Figure 8. The Face of Fu Manchu, An American thriller film directed by Don Sharp in 1965

In addition, influenced by anti-institutional ideological trend, there were voices arising from society calling for equality and self-liberation. The Mao suits, and other Chinese uniforms, were costumes produced in China to eliminate hierarchy, suggestive of a kind of rebellion against authority and orthodoxy. For this reason, uniforms had then become a new style of anti-fashion clothes and swept over western countries. In May, 1972, an article titled "The Fashion Influence Rudi Gernreich" in Harper's Bazaar introduced Rudi Gernreich, an anti-fashion pioneer designer, about his affinity for Chinese workers' blue uniform. He said, "The Haute Couture is offensive... Any public display of extreme affluence is resented...Centainly China is an influence...Every time I mention uniforms, people get nervous and think it has political overtones when actually uniforms are so logical and utilitarian-the real identity of a person shines through even more clearly." (Dinsmore, 1972, p. 10). 
Besides, uniforms such as Chinese tunic suits and workers' wear also conformed to the fashion concept of feminists. Anti-institutional social values had led to an increase in the number of western career women. Wearing menswear and trousers had become a means for women to pursue gender equality and greater social status. Women's pursuit for the same clothes with men won an opportunity for Chinese-influenced clothing with neutral characteristics. Gloria Laura Vanderbilt, an elite woman from the United States who was an artist, a writer, an actor as well as a designer in the 1970s, was a prominent representative of western career women. An article published in Vogue named "I like being who I am-Gloria Cooper" reported her career and life attitude. In Figure 9, Gloria was wearing a blue cotton Chinese uniform and worked in her studio. She said, "When I'm working, it is total, concentrated joy..." (Vogue, 1972 June 1, p. 79). Although her body curves were hidden behind rough fabrics, neutral design and dull colors of Chinese uniforms, they blurred the gender differences, highlighting women's desire of for work and equality by imitating the appearance of men.

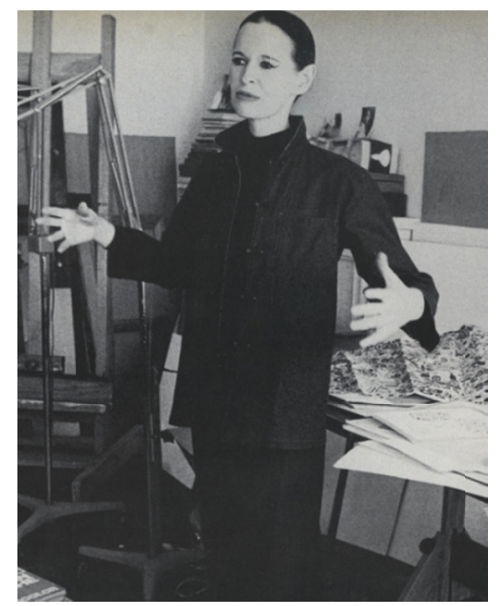

Figure 9. Gloria Laura Vanderbilt in Chinese uniform

Another inevitable result of anti-fashion trend is the value embodiment of urban enterprises, including the respect for nature and the regression to nature. In 1973, a nostalgia movement sprung up in the West. What could be got from the anti-fashion trend was the proposal for revolution of women's wear raised by naturalists. At the time, people preferred simpler, looser and more casual garments rather than having their body bound up. They dreamed to be free to do things as they like, and live delightedly during their lifetime. Casual clothing means simple cutting. In virtue of flat cutting method, the oriental-style clothing had already provided with all the requirements of women's wear revolution. Japanese designer Kenzo Takada, known for his oriental-style design work, said in the October-1971 issue of Advanced Fashion, "People are tired of perfect designs... Then, flat-cutting clothes...looks plain, attractive and amazingly fresh." (Zhang \&Yang,1992, p.392). Apparently, casual Chinese clothing based on flat cutting coincided with the pursuit of western consumers to body liberation and natural life regression.

\subsection{International Factors}

Apart from internal factors, international factors also played a part in the popularity of Chinese-influenced clothing. In the 1970 s, there once was a widespread saying that "China Look", which was partly a result of Sino-Western relation normalization, especially the relationship with the United States. An article entitled "Bazaar's China Chic" published in Harpers and Queen in December, 1971 attributed China's success in reform and opening-up to "The Nixon initiatives", "The Kissinger prove" and "The U.N. vote" (Harpers and Queen, 1971 December 1, p. 55). It was obviously a great political event that President Nixon made his historical visit to China in 1972 under the influence of ping-pong diplomacy. Ever since then, China became reopening to the western world. Fashion designers often inspired by major social events. Their skillful application of elements from social events in their design works could easily resonate with the broad masses, producing a bandwagon effect (Zhang, 2015, p. 3). In Women's Wear Daily issued on August 18, 1971, Leo Greer, a designer of Herald House said in an article named "The Year of the Chinese" that "China has always been a tremendous source of design, but it wasn't until President Nixon announced his visit that it seemed legitimate to use it."'(WWD, 1971 August 18, p. 4) .International events, to a certain extent, pushed forward fashion trends as an important external factor, and played a catalytic role in the prevalence of Chinese-style popularity in the West at that time.

What's more, western countries had experienced economic crisis and energy crisis in the early 1970s. As a result, mult-national companies rose in response to the economic crisis. To reduce production costs, these companies 
actively adopted labors from the Far East, including Hong Kong. Consequently, Hong Kong ushered in its economic boom and flourishing trade, attracting attention from western designers paid to Hong Kong's local culture and even Chinese culture. In this manner, Hong Kong turned into a major inspiration source of Chinese and Southeast Asian elements. An article entitled "Chinois Series" in the August 1975 issue of Harpers and Queen mentioned that "...many of our designers are having their ranges made up in Hong Kong and other stations east. It is inevitable that the trained eye of a professional designer will be influenced by the things that assault his eye on working trips to these exotic climes." (Harpers and Queen, 1975 August 1, p. 56). Moreover, Hong Kong has become a mirror of Chinese dress culture, with a large number of export goods providing western designers with Chinese-style samples and references. Women's Wear Daily reported on August 18, 1971 that "Carol Horn sees the Chinese influence as a new inspiration of 'exotic or workman's clothes." (WWD, 1971 August 18, p. 4). The report also included her self-report, "I had Chinese peasant clothes flown from Hong Kong to get an authentic look..." (Ibid). Hong Kong's role as a transit point connecting Chinese mainland and western capitalist countries had boosted the popularity of Chinese-style garments in the West.

\section{Conclusion}

Chinese-influenced clothing was a product of a certain historical stage with complex social background. In the 1970s, Chinese-influenced clothing included three categories: outdoor clothes, loungewear and evening dress. Outdoor clothes were mainly influenced by Han suits and Mao suits worn by Chinese workers and peasants. They were made of cotton, wool, silk and other natural fabrics, more stress laid on practical applicability. They had become the most popular Chinese-influenced clothes featuring simplicity, unadornedness, functionality and neutrality in the 1970s. Loungewear mostly included cheongsams and Han suits. In most cases, silk-based natural fabrics were adopted with much attention paid to comfort. Chinese-influenced loungewear gave an impression of leisure, tenderness, and romance. Evening dress stemmed from Manchu robes and cheongsams. They were rich in colors and diverse in decorations, looking graceful, luxurious and splendid with a combination of traditional Chinese attributes and contemporary international trends. The social origin for the 70 s popularity of Chinese-influenced clothing lay in the anti-fashion trend of thought led by western values of self-negation. The aesthetics of Chinese-influenced clothing in terms of economic value, class equality, gender equality and nostalgia were in line with the aesthetic requirements of anti-fashion in the West. International factors ranging from Sino-American relation normalization to Hong Kong economic boom also contributed to the popularity of Chinese-influenced clothing. However, the enthusiasm for Chinese-influenced clothing had gone through merely a short-term prosperity. Chinese fashion influence has long been considered a symbolic aesthetic of surface. With the expanding international impact of China, Chinese fashion along with its cultural value should be interpreted, shaped and advertised anew in a more essential way today.

\section{Acknowledgements}

This research has been financed by the Fundamental Research Funds for the Central Universities in 2018 (CUSF-DH-D-2018046); China Scholarship Fund (201806630051).

\section{References}

"I like being who I am" Gloria Cooper. (1972, June 1). Vogue, p. 79.

Advertisement: Fashion Quorum (1976, August 1). Vogue (New York edition), p. 37.

Anti-fashion (2019, November 3). In Wikipedia, the free encyclopedia. Retrieved November 3, 2019, from https://en.wikipedia.org/wiki/Anti-fashion

Bazaar's China Chic. (1971, December 1). Harpers and Queen (New York edition), p. 55.

Bian, X. Y. (2006). Apparel Art Judgment. Shanghai: Donghua University Press.

Bian, X. Y. (2014). History of Shanghai fashion in modern China. Shanghai: Donghua University Press.

Bolton, A. et al. (2015). Toward an Aesthetic of Surfaces. In A. Bolton et al. (Eds.), China Through the Looking Glass (pp. 18-19). New Haven: Yale University Press.

Chinois Series. (1975, August 1). Harpers and Queen (New York edition), p. 56.

Delong, M., Wu, J., \& Bao, M. (2005). The influence of Chinese dress on Western fashion. Journal of Fashion Marketing and Management, 9(2), 166-179. https://doi.org/10.1108/13612020510599321

Dinsmore, N. (1972, May 1). The Fashion Influence Rudi Gernreich. Harpers and Queen (New York edition), p. 10.

Fashion: Paris Couture: Splendour, Seduction...The Pleasure Principle. (1977, October 1). Vogue, p. 263. 
Fashion: The Chinese Slant in Fashion (1971, November 15). Vogue (New York edition), p. 68.

Kim, H., \& DeLong, M. (1992). Sino-Japanism in Western women's fashionable dress in Harper's Bazaar, 1890-1927. Clothing and Textiles Research Journal, 11(1), 24-30. https://doi.org/10.1177/0887302X9201100104

Mao suit. (2019, October 27). In Wikipedia, the free encyclopedia. Retrieved October 27, 2019, from https://en.wikipedia.org/wiki/Mao_suit

Rado, M. M. (2015). Imagery of Chinese Dress. In A. Bolton et al. (Eds.), China Through the Looking Glass (p. 50). New Haven: Yale University Press.

Shi, Y. J. (2018). On Anti-fashion and Its Logic. Art \&Design Research, 80(2), 10. https://doi.org/1674-7518(2018)02-0010-06

Steele, V., \& Major, J. (1999). China Chic: East Meets West. New Haven: Yale University Press.

Szeto, N. Y. (1997). Cheungsam: Fashion, culture and gender. In C. Roberts (Eds.), Evolution \& Revolution Chinese Dress 1700s 1990s. Sydney: Powerhouse Publishing.

The Year of the Chinese. (1971, August 18). Women's Wear Daily (p. 4).

Xu, Q. Q. (2003). Research on Chinoiserie in Western Fashion Design (Master's thesis, Donghua University, Shanghai, China). Available from China National Knowledge Internet: Full Text.

Yu, H., Kim, C., Lee, J., \& Hong, N. (2001). An analysis of modern fashion designs as influenced by Asian ethnic dress. International Journal of Consumer Studies, 25(4), 309-321. https://doi.org/10.1046/j.1470-6431.2001.00200.x

Zeng, Y. (2011). Chinese influence on western women's dress in American Vogue magazine, 1960-2009 (Doctoral dissertation). Louisiana State University, Louisiana, the USA.

Zhang, N. R., \& Yang, A. Q. (1992). History of the World Costume. Beijing: People's Fine Arts Publishing House.

Zhang, X. (2015). Clothing in Fashion. Beijing: China Textile \& Apparel Press.

Zhou, X., \& Gao, C. (1984). 5000 years of Chinese costumes. Hong Kong: C \& C Joint Printing Co.

\section{Copyrights}

Copyright for this article is retained by the author(s), with first publication rights granted to the journal.

This is an open-access article distributed under the terms and conditions of the Creative Commons Attribution license (http://creativecommons.org/licenses/by/4.0/). 